\title{
ГОСУДАРСТВЕННАЯ АГРАРНАЯ ПОЛИТИКА: ПРОБЛЕМЫ ОБЪЕКТИВАЦИИ
}

\begin{abstract}
Аннотация: Эффективность государственной аграрной политики определяется соответствием ее содержания природе сельского хозяйства, его объективной данности. В связи с этим приоритетной задачей указанной политики является обеспечение симбиоза субъективного с объективным, устранение противоречий между ними, отказ от негативного отношения к природному, естественному в аграрной экономике. Объективация аграрной политики государства как результат его деятельности в сельском хозяйстве рассматривается в статье как проиесс осознания и познания объективных закономерностей природы и общества. Вызовы современности требуют наличия политического интереса государства к проблемам развития аграрного сектора, который должен объективироваться в конечном счете в повышении эффективности и устойчивости сельскохозяйственного производства. Ключевые слова: Политология, государство, политика, право, аграрный, экономика, объективация, природа, событие, субъективация
\end{abstract}

XXI век Россия вошла как держава, характеризующаяся отсталостью сельского хозяйства и агропромышленного комплекса (АПК), зависимостью продовольственного обеспечения населения страны от зарубежья и потерей своей продовольственной безопасности. Судя по опубликованным ВНИИЭСХ в печати данным, в стране продолжалось падение аграрного производства на 43,3\%, в 26 раз возросла доля убыточных организаций, в 4 раза сократилась доля сельского хозяйства в валовой добавленной стоимости, почти на 10\% упал валовой сбор зерна, на $56 \%$ уменьшилось поголовье крупного рогатого скота, как следствие этого, рентабельность сельхозорганизаций по сравнению с уровнем 1990 года упала в 2,8 раза, сократилась посевная площадь на $34,8 \%{ }^{1}$. Как это ни парадоксально, такой «успех» был достигнут «несмотря на очень высокий потенциал России - наличие 9\% мировой продуктивности пашни, более 50\% мировых черноземов, 20\% мировой пресной воды, производств почти $9 \%$ мирового объема удобрений»².

Выход из создавшегося положения, как это заложено в Стратегии инновационного развития Российской Федерации на период до 2020 года ${ }^{3}$ и в Государственной программе развития сельского хозяйства и регулирования рынков сельскохозяйственной продукции, сырья и продовольствия на 2013-2020 годы ${ }^{4}$, государство видит в

\footnotetext{
${ }^{1}$ АПК: экономика, управление. 2013. № 1. С. 190.

2 Ушачев И. Система управления - основа реализации модели инновационного развития АПК России // АПК: экономика, управление. 2013. № 1. С. 13.

${ }^{3}$ Утверждена Распоряжением Правительства Российской Федерации от 8 декабря 2011 года № 2227-p // www.consultant.ru.

${ }^{4}$ СЗ РФ. 2012. № 32. Ст. 4549.
}

переходе экономики АПК на инновационную социально ориентированную модель развития, носящую доминантно субъективный, догматический, по существу дискреционный характер 5 . На наш взгляд, предлагаемый переход основывается на неподтвержденной хозяйственной практикой ущербной, волютнтаристической по содержанию, господствовавшей и господствующей поныне, научно необоснованной, а потому не могущей быть объективированной, аграрной политике государства. Доказательство тому - вся история безуспешного, низкорезультативного ведения отечественного сельского хозяйства, маскируемого победными реляциями о торжестве ленинской аграрной политики государства, на деле сводящегося к колоссальному импорту продовольствия из-за рубежа, игнорированию большинства научно обоснованных рекомендаций научной общественности ${ }^{6}$ и отрицатель-

\footnotetext{
${ }_{5}^{5}$ Ханнанова T.P. Аграрная политика государства: критика догмы // Теория и практика общественного развития. 2013. № 2.

${ }^{6}$ Алтухов А. Новые проблемы развития зерновой отрасли // АПК: экономика, управление. 2011. № 1. С. 10-21; Романенко Г. Обеспечить модернизацию агропромышленного комплекса // АПК: экономика, управление. 2011. № 3. С. 3-10; Шутьков А. Аграрная политика: социально-экономические проблемы // АПК: экономика, управление. 2011. № 5. С. 3-9; Буздалов И. Земельная реформа: взгляд сквозь призму замысла // АПК: экономика, управление. 2012. № 7. С. 3-17; Ушачев И.Г. О мерах по обеспечению конкурентноспособности продукции Российского сельского хозяйства в условиях присоединения к ВТО // Агропроизводственная политика России. 2012. № 7. С. 2-7; Ушачев И., Алтухов А. Территориальноотраслевое разделение труда - основной фактор развития агропромышленного производства России // АПК: экономика, управление. 2011. № 8. С. 3-12; Ушачев И. Экономический механизм реализации Государственной программы развития сельского хозяйства и регулированиярынков сельскохозяйственной продукции, сырья и продовольствия на 2013-2020 годы // АПК: экономика, управление. 2012. № 11. С. 3-7; Ушачев И. Система управление- основа реали-
} 


\section{Право и политика $4(160) \cdot 2013$}

ной реакции населения на бездействия органов власти и хозяйственного управления, на недостатки и отставание аграрного сектора экономики страны и на преступное отношение к прогрессивному опыту осуществления сельскохозяйственного производства, на неумолимо продолжающийся развал организационно-правовых форм сельских товаропроизводителей, растранжирование их имущества под видом проведения аграрных реформ и преобразований и т.д. и т.п., использование специально для этого созданных правоустановлений, «узаконений».

Дискреционность (ADISCRETION, ADLIBITUM) национальной аграрной экономики косвенно признается и нормативными актами государства типа доктрин, концепций, стратегий, государственных целевых программ и т.п. документов и основанными на них актами․ Не случайно в свое время Председатель Правительства Российской Федерации В.В. Путин признал факт деиндустриализации, сильную деформацию структуры экономики и необходимость новой экономики с эффективным сельским хозяйством, функционирующим на принципах технологической кооперации, взаимной зависимости, укрепляющей не только экономическую, но и политическую стабильность ${ }^{8}$, опирающуюся на природоресурсные и духовные (объективные и субъективные) составляющие процесса доходного хозяйствования.

Разработка Государственной аграрной политики и легитимация ее в форме особого документа является важным первоначальным шагом государства в направлении ее опредмечивания, т.е. объективации, перевода содержания в плоскость (сферу) реальной действительности. Эта одна сторона проблемы. Другая сторона проблемы состоит в том, что обозначаемая политика должна объективироваться на деле (INRE), воплощаться (воплотиться) в чем-нибудь объективном, доступном восприятию ${ }^{9}$, считаться принадлежностью конкретных предприятий, организаций, фактором производства и «...элементом и со-

зации модели инновационного развития АПК России // АПК: экономика, управление. 2013. № 1. С. 13-21; Воронин Б.А., Ханнанов Р.А., Ханнанова T.P. Новые концептуальные основы обеспечения устойчивости аграрного производства // Аграрный вестник Урала. 2012. № 6. С. 81-89; Ханнанов Р.А., Ханнанова Т.Р. Кластеризация экономики и государственная кластерная политика: теоретические основы и социально-экономические предпосылки // Евразийский юридический журнал. 2012. № 12. С. 129-135.

${ }^{7}$ Концепция долгосрочного социально-экономического развития Российской Федерации на период до 2020 года http://base. garant.ru/194365/; Государственная программа развития сельского хозяйства и регулирования рынков сельскохозяйственной продукции, сырья и продовольствия на 2008 - 2012 годы http://base.garant.ru/2162858/ .

${ }^{8}$ Путин В.В. О наших экономических задачах // Ведомости 2012. 30 января.

${ }^{9}$ Крысин Л.П. Толковый словарь иноязычных слов. - М.: Эксмо, 2007. -944 c. - С. 534. циальной сферы, характеризуемым как объект, в котором сосредоточена или на который направлена экономическая деятельность, и предопределяющим определенную сторону экономических интересов и отношений» ${ }^{10}$. И только при подобном понимании рассматриваемая политика может объять субъекты агрохозяйственных отношений, иметь свои пространство, время, предмет, основания и характер оценки общеполезности и быть инициатором преобразований в сельском хозяйстве и АПК. Именно такое понимание формирует оценочные суждения об обусловленности субъективного объективным, рациональности совместного влияния их на сознание и экономически оправданное поведение и эффективную деятельность аграриев, тем самым становясь объективным элементом проводимой государством в этой области отношений политики.

Обновление экономики страны, в первую очередь аграрной, немыслимо без модернизации и пересмотра действующей в настоящее время дискреционной аграрной политики государства, без ее решительной (FERMO) перестройки в полном составе (INCORPORE), создания на этой базе новой одноименной политики, способной оказать объективирующее ценностное воздействие на весь спектр агрохозяйственной деятельности (ENMASSE). Это означает, что политика, прежде всего, предполагается как нечто композитивное, состоящее из свойства - качественного образования, способного существовать независимо от субъекта, стремящегося вникать в содержание дела, и, в то же время, подвергаемое субъективному опосредованию - осмыслению указанного дела в рамках определенного концепта. Применительно к рассматриваемой проблеме аграрная политика является результатом взаимодействия взаимообусловленных объективного (независимого) и субъективного (взглядов, точек зрения, предпочтений, интересов и т.д. группы лиц, общества, организованного в государство народа), находящихся между собой в неантагонистической систематической бинарной оппозиции. И только взятые в единстве и целостности (ENGROS) они дополняют и поддерживают друг друга, формируя надежную почву для достижения устойчивости и эффективности аграрного производства. Происходящее таким образом взаимодействие объективного и субъективного редуцирует (REDUCTIO) позитивную агрохозяйственную деятельность, восстанавливает ее подлинную социально-экономическую природу в целостности (RESTITUTIOININTEGRUM), чем открывает путь к дальнейшему развитию сельской отрасли и агропромышленного комплекса.

Предлагаемый подход к пониманию сущностной основы возрождения аграрной политики государства должен восприниматься в ходе ее исторического бытия, и

\footnotetext{
${ }^{10}$ Новый экономический словарь / Под ред. А.Н. Азрилияна. - М.: Институт новой экономики, 2006. - 1088 с. - С. 467.
} 
Государственные институты и правовые системы

действительно воспринимается человеком, обществом как непосредственная данность, как нечто объективное, как событие, инициирующее объективизацию государственного влияния на аграрную экономику. Поэтому создание и поддержание баланса между объективацией и субъективацией в сфере аграрного производства, агрохозяйственной деятельности, предстоит признать руководящим принципом названной политики. Без такого признания последняя теряет свои регулятивные качества и свойства, превращается в бесполезное, в частности, неудачные реформаторские усилия, имевшие место в агропроме.

Объективация аграрной политики государства выступает, прежде всего, в виде особого процесса осознания и познания объективных закономерностей природы и общества. История становления и развития общества подтверждает, что жизнедеятельность человека обуславливалась прогрессом экономических отношений собственности, в первую очередь, связей, носящих земледельческий характер. Ограниченный доступ к природным ресурсам, пище заставили человека заняться поиском пищевых, потребляемых ресурсов, осуществляемым им (ABINCUNABULIS) инстинктивно, затем рефлекторно, в конечном счете, осознанно, избирательно. Произошедшие в рамках общественного строя три крупных разделения труда (отделение ремесла от земледелия, выделение пастушеских племен из родоплеменного сообщества, появление класса купцов), то есть факторы объективного, событийного порядка, предопределили появление частной собственности на материальные блага и классов с антагонистическими интересами, а также особого аппарата, призванного управлять неимущим большинством в интересах имущего меньшинства, называемого государством ${ }^{11}$, реализующим свою деятельность в форме политики, в том числе и аграрной. Последующее развитие экономики страны показало и доказало, что объективная природа политических действий в сфере аграрной экономики, в организации и реализации отношений собственности, не нашла своего подтверждения ${ }^{12}$. Пример тому - принудительно проведенная коллективизация крестьянства, неучет при такой кооперации объективно сформировавшейся психологии хозяина производства и собственника произведенной продукции, как следствие этого, отсутствие интереса крестьянства к созидательной деятельности, постепенное отставание сельскохозяйственного производства, его отсталость. Непризнание событийности, возбуждающей стремление к государственному влиянию на «непосред-

\footnotetext{
11 Энгельс Ф. Происхождение семьи, частной собственности и государства // Маркс К., Энгельс Ф. Соч. 2-ое изд. Т. 21. С.

${ }^{12}$ Ханнанов Р.А., Ханнанова Т.Р. События в системе правового обеспечения модернизации социально-экономического развития России: теория и практика. - Уфа, Башкирский ГАУ, АН РБ, 2012. - 162 c. - C. 44.
}

ственную данность», объективно наличествующей в аграрном производстве, привели к ущербному решению - упразднению всех колхозов, даже функционирующих на рентабельной основе. Игнорирование тотального свойства саморегулирования отношений, имманентно присущего закону природы и сущности связей собственности в изложенном смысле, оказало неизбежное воздействие на выбор политических способов вредоносной организации агрохозяйственной деятельности. Имущество, принадлежащее колхозам (ныне всем аграрным предприятиям), большей частью «объективировалось» под видом проведения институциональных преобразований либо банкротства, оказалось разбазаренным с ведома действующих политических структур власти.

Сложная экономическая ситуация обусловливает повышение требований к темпу и качеству развития сельского хозяйства и АПК, переводу биотехнологий на инновационный путь осуществления. Изменение климата, проблемы в области обеспечения продовольственной безопасности объявляются вызовами, предопределяющими необходимость опережающего развития агропрома на базе внедрения новых технологий в сельском хозяйстве (пункт 1 раздела II Стратегии инновационного развития России). В переводе на более доступный язык речь идет об обстоятельствах, формирующихся и носящих объективный, неволевой, событийный, а потому требующий адаптации, характер. Эти обстоятельства в своем возникновении или в процессе объективации, превращения в реальность не зависят от устремления участников общественных, социально-экономических отношений, но могут и должны подвергаться познанию, объективироваться. В качестве таковых в реальной действительности выступают порожденные природой явления (засухи, избыточные увлажнения, эпизоотии, инсектиционные нашествия и т.п. и т.д.), проявления закона саморегуляции природы, а также субъективно возбужденные в силу их многократного повторения в течение длительного времени обстоятельства, переросшие в нечто объективное в форме социальных событий, превращенные в «непосредственные данности», подлежащие охвату содержанием аграрной политики государства (социальная напряженность, экономическая отсталость, кризисы, общественная пассивность, безразличие к свершенному и массовому самосохранению, отказ от приверженности к сельской жизни и труду, аграрному производству, биогенная загрязненность и др. особые состояния) ${ }^{13}$.

Вызовы подобного рода,казалось бы, достаточно очевидны. Как указывалось выше, история развития аграрного сектора экономики, к сожалению, подтверждает иное.

\footnotetext{
${ }^{13}$ Подробно об этом см. Ханнанов Р.А., Ханнанова T.P. События в системе правового обеспечения модернизации социально-экономического развития России: теория и практика. С. 102-106.
} 


\section{Право и политика $4(160) \cdot 2013$}

Объективное в аграрной деятельности и аграрной политике нередко декларируется, но на деле «не замечается» в пользу субъективного, догматического, дискреционного ${ }^{14}$, что рельефно видно из содержания нормативных актов своего времени ${ }^{15}$ и отдельных примеров, имевших либо имеющих место в агрохозяйственной деятельности.

В недалеком прошлом (60-70 годы 20 века) в стране проводилась многозатратная компания мелиорации земель. Под предлогом повышения уровня плодородия земель (объективного составляющего земледелия), преодоления зависимости аграрного производства от неблагоприятных воздействий капризов природы, расширения посевных площадей, обеспечения роста уровня кормоснабжения животноводства были предприняты меры по осушению и обводнению земельных угодий, осуществлены другие хозяйственные мероприятия по повышению отдачи от производственного потенциала отрасли. Проведенная без учета природного фактора (необходимости сохранения производящих способностей окружающей среды лишь в рамках естественных непосредственных данностей) мелиорация завершилась уничтожением природного базиса сельского хозяйства, лесов, выполняющих функции борьбы с эрозией земель, водоисточников (родников и болот как естественных резервуаров пресной воды, используемых для орошения сельскохозяйственных культур), сокращением и, даже, ликвидацией среды произрастания плодоносящих деревьев и кустарников (ягодников, плантаций лещины и других орехоплодных, грибов), уходом и сокращением поголовья обитающих в естественных условиях диких животных (оленей, лосей, косуль и др.), словом, - нанесением неустранимого поныне урона всей флоре и фауне. «Мелиорация» открыла путь к нарушениям утвердившихся (устоявшихся) процессов воздушного бассейна, усилению вредного ветрового воздействия на аграрное производство, развитию водной и ветровой эрозии почвы, в конечном счете, - подрыву биоресурсной основы аграрного производства, снижению урожаев культур и сборов растениеводческой продукции, падению продуктивности животных и объемов производства животноводческой продукции, созданию условий для возникновения болезней растений и животных, прогрессированию вредных для сельского хозяйства насекомых (саранча, колорадский жук, жук-проволочник и т.п.).

\footnotetext{
${ }^{14}$ Ханнанова Т.P. Концептуальные основы аграрной политики // Мир и политика. 2013. № 2. С.

${ }^{15}$ Постановление ЦК КПСС и Совета Министров СССР от: 16 июня 1996 года «О широком развитии мелиорации для получения высоких и устойчивых урожаев зерновых и других сельскохозяйственных культур» // Решения партии и правительства по сельскому хозяйству (1965-1974 гг.). - М.: Колос, 1975. С. 125-129; от 20 марта 1967 года «О неотложных мерах по защите почв от ветровой и водной эрозии» // СП СССР. 1967. № 9. С. - 145: Статьи $1,12,13,71,72,94$ действующего Земельного кодекса РФ и др.
}

Аграрная политика государства того периода полностью проигнорировала требования закона саморегуляции природы, не смогла мобилизовать сельских товаропроизводителей на ведение сельского хозяйства, прежде всего, на объективно обусловленной основе, чем способствовало потере им свойства самовозрождения (саморегулирования), утверждению дискреционного ущербного режима осуществления.

В настоящее время площадь мелиорируемых земель ничтожна и составляет лишь 7,9\% от площади пашни ${ }^{16}$.

Очевидным вызовом изложенного толка является и повсеместная потеря плодородия почв земель сельскохозяйственного назначения. За период до 2010 года были разработаны и приняты три нормативных акта, в т.ч. две федеральные целевые программы сохранения и повышения плодородия почв ${ }^{17}$, находящихся в пользовании сельских товаропроизводителей. Однако эти документы так и остались на бумаге, не реализовались, и в условиях распада имеющихся хозяйств, их повального банкротства, разбазаривания имущества, ликвидации деревень и ухода из них населения, особенно его трудоспособной части, программы не смогли найти свое место в системе агрохозяйственной деятельности, остаются пребывать в состоянии декларативных актов государства. Земли сельскохозяйственного назначения абсолютно лишены возможности получать органические удобрения (навоз, компосты, торф), во-первых, в хозяйствах из-за сокращения поголовья скота их вообще нет, естественно, они не могут накапливаться и обрабатываться, во-вторых, если даже они где-то и имеются, из-за большего объема не могут транспортироваться на отдаленные участки земледелия, и, в-третьих, из-за заброшенности земельных долей, отсутствия к ним имущественного интереса со стороны земледельцев, ставших номинальными собственниками. Не внедряется в производство по указанным причинам и оправдавшая себя в отдельных хозяйствах адаптивноландшафтная система земледелия. Из-за игнорирования системы ведения сельского хозяйства системы формально имеются повсеместно, но не исполняются. Вследствие этого аграрное производство России держится на есте-

\footnotetext{
${ }^{16}$ Раздел I Концепции федеральной целевой программы «Развитие мелиорации земель сельскохозяйственного назначения России на 2014-2020 годы» // С3 РФ. 2013. № 4. Ст. 303.

17 Закон Российской Федерации от 16 июля 1998 г. «О государственном регулировании обеспечения плодородия земель сельскохозяйственного назначения» // СЗ РФ. 1998. № 29. Ст. 3399; Постановления Правительства Российской Федерации от: 17 ноября 2001 г. «О федеральной целевой программе «Повышение плодородия почв России на 2002-2005 годы» // СЗ РФ. 2001. № 48. Ст. 4515; 20 февраля 2006 г. и «О федеральной целевой программе «Сохранение и восстановление плодородия почв сельскохозяйственного назначения и агроландшафтов как национального достояния России на 20062010 годы и на период до 2013 года» // СЗ РФ. 2006. № 10. Ст. 1101.
} 
Государственные институты и правовые системы

ственном, сформировавшемся веками, плодородии ${ }^{18}$ и находится в состоянии выживания. Произошло это, в первую очередь, из-за неучета важности объективного фактора - биологического свойства почв, плодородия, отсутствия к ним политического интереса со стороны органов государственной власти и агрохозяйственного управления. Без такого интереса немыслимо предотвращение эрозионных процессов, происходящих в земледелии, тотальной потери гумуса в почве и, как следствие этого, утраты основного полезного, объективно присущего свойства почвы, достижение намеченных к производству объемов сельскохозяйственной продукции и соблюдение нормативов их потребления на душу населения, которые, к примеру, по зерну составляют 1 т. на каждого россиянина, а для всего населения - более 140 млн. т. в год. Известно, что таких показателей производства зерна Россия никогда не имела, ибо оно велось без учета объективного фактора (события) - снижения плодородия почв и соответствующего содержанию этого фактора политического воздействия на сельскохозяйственное производство, что ясно прослеживается из данных государственных органов статистики и подтверждается фактом неисполнения федеральной целевой программы «Юг России 2008-2013 годы» ${ }^{19}$.

Следующим вызовом, формирующим объективную часть аграрной политики государства, является биологически предопределенная зависимость сельскохозяйственных культур от водопотребления и водообеспечения. Вся технология сельскохозяйственного производства построена на использовании пресной воды. Запросы ее, особенно в районах интенсивного осуществления аграрного производства, ограничиваются. Недостаток пресной воды создает ситуацию, частично или полностью парализующую процессы развития растений и животных, пагубно отражающуюся на экономических результатах производства, сопровождается снижением урожайности, сборов, либо утратой продуктивности и объемов животноводческой продукции, свертыванием производственных возможностей сельских товаропроизводителей, ухудшением их финансового состояния. В этой связи уместно отметить, что на аграрное производство оказывает пагубное воздействие негативное и отчасти халатное отношение государства и самих товаропроизводителей к объективно существующей необходимости сохранения и обустройства природных водоисточников (родников, болот, сбору дождевой воды,

\footnotetext{
${ }^{18}$ Алтухов А. Новые проблемы развития зерновой отрасли // АПК: экономика, управление. 2011. № 1. С. 14; Ушачев И., Алтухов А. Указ. работа; Хицков И. Системность - определяющий фактор разумного хозяйствования // АПК: экономика, управление. 2012. № 8. С. 13-14 и др. с изменениями и дополнениями от: 4 июня 2007 г., 7 марта 2008 г., 16 марта, 3 октября 2009 г., 21 апреля, 26 июля 2012 г., 17 марта, 12 августа 2011 г., 14 июля, 27 декабря 2012 г.

${ }^{19}$ Федеральные целевые программы России http://fcp.economy.gov. ru/cgi-bin/cis/fcp.cgi/Fcp/ViewFcp/View/2008/248.
}

снегозадержанию, сохранению прибрежных лесов, облесению территорий естественных водных объектов и т.д., учету и паспортизации водных объектов и других форм их объективации. Исключительное, естественное, имманентно присущее, проистекающее из природы растений и животных водопотребление (объективное свойство) должно устойчиво закрепляться, объективироваться в деятельности сельских водопотребителей и легитимироваться в Государственной аграрной политике. Оно должно занять подобающее место в документах типа рекомендаций, стратегий, систем ведения подотраслей хозяйства и т.п. (недопущение пресловутой плужной подошвы, селекция на засухоустойчивость путем внедрения в севооборот культур со стержневой корневой системой, таких растений, как козлятник восточный, люцерна посевная, клевер; гибридизация животных с сокращенными объемами водопотребления путем скрещивания породных животных с представителями приспособленных к засушливым условиям их природных братьев и сестер, имплантация и др., т.е. использование объективных средств уменьшения водопотребления, вовлечение самой природы (объективного)в создание и развитие устойчивости производства, независимости его от климатических изменений и природных аномалий. При подобном подходе к делу природа начинает работать на себя, предвосхищая позитивные результаты от внутренне обусловленного хода событий и преодоления последствий ветровой эрозии и опустынивания сельскохозяйственных угодий, достигших к настоящему времени размера 1201 тыс. гектаров по России $^{20}$, требующих орошения. Не могут оставаться вне внимания аграрной политики глобальные и региональные изменения климата и природо-ресурсного (водного) потенциала, вызывающие и активизирующие свои конкретные проявления в виде событий (наводнений, подтоплений и затоплений, морального и физического износа сооружений и оборудования водохозяйственного назначения, аварийной, т.е. повышенной опасности ${ }^{21}$, приводящей к непредсказуемым чрезвычайным ситуациям и техногенным катастрофам, биологической и фитосанитарной усталости почв, а также изменений общегосударственной экономической политики по поддержке агропромышленного

\footnotetext{
${ }^{20}$ Федеральные целевые программы: «Развитие водохозяйственного комплекса Российской Федерации в 2012-2020 годах», утв. Правительством Российской Федерации 19 апреля 2012 года // С3 РФ. 2012. № 18. Ст. 2219; Концепция Федеральной целевой программы «Развитие мелиорации земель сельскохозяйственного назначения на 2014-2012 годы», утв. Правительством Российской Федерации Распоряжением от 22 января 2013 года. № 37-р // С3 РФ. 2013. № 4. Ст. 303.

${ }^{21}$ Ханнанов Р.А. Правовое регулирование сельскохозяйственного производства. - Уфа: Ульяновский СХИ, 1976. - 5-20, 63-86; его. же. Природа, право, юридические события. - Уфа.: Баш. ГАУ, 2009. 112 c. - C. $40-47$.
} 


\section{Право и политика $4(160) \cdot 2013$}

комплекса, ухудшения внутренней и внешней конъектуры рынка, снижения темпов роста аграрной экономики, высокой инфляции, продукционного потенциала земли и т.Д., т.е. всего того, учет чего способен решить проблему водообеспечения сельскохозяйственного производства). Действия по претворению в жизнь предопределенных такого рода объективными проявлениями событий должны включать достижение намечаемых объемов производства продукции, инвестиционную привлекательность водообеспечения, выполнение государственного заказа.

Для полного обоснования рассматриваемой проблемы остановимся на объективных составляющих аграрной политики в подотрасли животноводства.

Животноводство относится к специфической сфере человеческой деятельности, испытывающей воздействие объективных условий природы в полной мере их бытия. Его становление и развитие обусловлены наличием двоякого рода естественных, генуинных факторов. В состоянии зарождения (INSTATUNASCENDY) оно представлялось в виде исключительно природного явления, с одной стороны, а в процессе развития - в виде некоего представляемого в форме «непосредственной данности», переросшей из субъективного в объективное, социальное событие (экономическую отсталость). Во веки веков (INSAECULASAECULORUM) российское животноводство находилось в состоянии упорно складывающейся отсталости, что воспринималось как должное в системе агрохозяйственности деятельности.

Однако сложившаяся ситуация в сфере продовольственного обеспечения, тотальная зависимость страны в снабжении населения продукцией животноводческого происхождения потребовали достижения прогресса в подотрасли, который может быть достигнут лишь при решительном отказе от устоявшихся стереотипов неизменности существующего положения, учете в организации и ведении животноводства обстоятельств природного характера, игнорирование которых инициирует и оправдывает низкую результативность хозяйствования. К их числу можно и нужно отнести такие объективные обстоятельства, как естественная обусловленность жизненного цикла животных, употребление ими пищи органического происхождения, предопределяющее особенности кормообеспечения, наличие природно-генетической специфики их развития и размещения, перманентность животноводческой деятельности, постоянство ее осуществления (PERMANENTIS), периодичность проявления отдельных природных свойств организма (PERIODIKOS), стадийность и стадность развития, свойство приспособляемости животных к условиям существования (ADAPTATIO). В ряду подобных обстоятельств следует указать также и их негативные, саморазрушающие свойства (инбридинг и приверженность продуктивных качеств к исчезновению, вырождение устойчивых к неблагоприятным условиям существования местных пород животных и другие формы самовосстановления (саморазвития либо саморазрушения) природного саморегулирования).

Аграрная политика должна быть построена на признании и познании подобных обстоятельств. Практика хозяйствования доказывает обоснованность данного утверждения. Отрицательное отклонение от объективно происходящих процессов привело к отставанию производства животноводческой продукции, отсталости подотрасли, спровоцировали (PROVOCARE) импорт практически всех ее видов в значительных объемах, породили и ввели в оборот понятие импортозамещения. Именно по таким и им подобным причинам в федерации и ее регионах были свернуты овцеводство, частично козеводство и свиноводство, мясное скотоводство, табунное коневодство, не может развернуться отечественный ареал дикого оленеводства, не формируются стада яков и овцебыков, нет тонкорунного овцеводства, каракулеводства, колоний бортевого пчеловодства. В итоге фактически утвержденной абъюрации (ABJURATIO), отречения от убежденности в значимости общественного становления и развитие национального животноводства Россия вынуждена довольствоваться завозом в страну заграничной, не всегда доброкачественной продукции в баснословных размерах, уйти с рынка производства и труда, тем самым создавая условия для сокращения зарубежной безработицы.

Объективное в аграрной экономике является основанием для сознательной организации и ведения всей агрохозяйственной деятельности в стране. Оно становится постижимым только в процессе интеллектуального опосредования сознания, субъективной его оценки с позиций эффективности, то есть критической субъективации, осуществляемой в доктринальной и концептуальной догмах $^{22}$. Аграрное производство невозможно без оценок его как явления реальной действительности, нуждающегося в преобразованиях в рамках сложившейся и существующей в аграрной экономике «неопосредованной данности». Смысл субъективации объективного, по удачному выражению Атаманчука Г.В., сводится к сближению субъективного с объективными закономерностями и формами общественной жизнедеятельности, приданию ему свойства обусловленности и обоснованности, и, таким

\footnotetext{
22 Доктрина продовольственной безопасности Российской Федерации, утв. Указом Президента Российской Федерации от 30 января 2010 г. № 120 // E-mail: info@gov.mcx.ru; Концепция долгосрочного социально-экономического развития Российской Федерации на период до 2020 года, утв. Распоряжением Правительства Российской Федерации от 17 ноября 2008 г. № 1662 - p; Климатическая доктрина Российской Федерации / http: www/Kremlin.ru./ news/6365; Концепция Федеральной целевой программы «Развитие мелиорации земель сельскохозяйственного назначения России на 2014-2020 годы», утв. Распоряжением Правительства Российской Федерации от 2 января 2013 г. № 37-p.
} 
образом, обеспечения рациональности его влияния на сознание, поведение и деятельность людей ${ }^{23}$. При таком подходе к субъективации она реально включается в процессы, происходящие и в аграрном производстве, в сферу политического влияния и регулирования, предотвращая произвольные, оторванные от жизни «мероприятия» типа проведенной на субъективистской основе аграрной реформы в России.

Теоретическая сторона субъективации, осуществляемой в аграрной экономике (сущность, субъективный фактор, его элементный взаимодействующий состав, процессное развитие направлений и общие результаты воздействия на аграрное производство, легитимация), уже была предметом нашего исследования, нашла развернутое отражение в опубликованных источниках научной информации ${ }^{24}$. На этой базе и исходя из нее проведен сравнительный индикативный анализ становления и развития государственной аграрной политики. Проблема же лежит в плоскости связи объективного с субъективным, в рационализации отношений по обеспечению объективного с субъективным, в правильном отражении последнего в объективной действительности, в организации агрохозяйственной деятельности, в активизации последствий политического влияния на развитие аграрного производства в устойчивом и эффективном режимах ${ }^{25}$.

Аграрная политика государства является весьма подвижным явлением действительности, охватывающим композитивную область бытия - сложную отрасль экономики страны, обладающую, поэтому, вариативной структурой существования, осуществления. Внешние проявления ее сводятся к приобретению объективного, выражаемого в виде практической деятельности по обеспечению производства сельскохозяйственной продукции, действий, по преимуществу поступков ${ }^{26}$, а иногда даже бездействий (невмешательства в развитие позитивного

\footnotetext{
${ }^{23}$ Атаманчук Г.В. Теория государственного управления: курс лекций / Г.В. Атаманчук. - 4 изд., стер. - М.: Омега-Л, 2006. - 384 c. - C. 456 .

${ }^{24}$ Воронин Б.А., Ханнанов Р.А., Ханнанова Т.Р. Новые концептуальные основы обеспечения устойчивости аграрного производства // Аграрный вестник Урала. 2012. № 6. С. 81-89; Ханнанова Т.P. Концептуальные основы аграрной политики // Мир и политика.

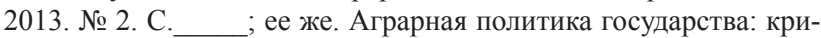
тика догмы // Теория и практика общественного развития. 2013. № 2. C.

${ }^{25}$ Воронин Б.А., Ханнанов Р.А., Ханнанова Т.Р. Современные проблемы правового регулирования аграрных отношений // Аграрный вестник Урала. 2012. № 10. С. 52-56.

${ }^{26}$ Ханнанов Р.А., Ханнанова Т.Р. События в системе правового обеспечения модернизации социально-экономического развития России: теория и практика. - Уфа.: Башкирский ГАУ, АН РБ, 2012.
} - 162 c. - C. $162-171$. в хозяйствовании $)^{27}$. В ходе ее проведения происходит опредмечивание мыслительного процесса. Он преобразуется в нечто воспринимаемое, в объект, объективацию государственного в общественное состояние действительности на уровне повседневной очевидности. Становление и бытие аграрной политики опосредствуются, большей частью, нормативными, законодательными правилами, в остальной части - ненормативными правилами, социальными нормами поведения участников аграрных отношений. Нормативные средства, как свидетельствует практика управления аграрной экономикой, используются в рамках руководства всей аграрной отраслью, ее отдельными подотраслями (растениеводством, животноводством), сферами технико-технологического, научного и финансового, информационного обеспечения осуществления государственной аграрной политики, имеющими важное и решающее значение для развития аграрной экономики (селекция и семеноводство, племенное дело, сохранение и повышение плодородия земель сельскохозяйственного назначения, орошение и осушение земель, водообеспечение, мелиорация, химизация, реализация систем ведения сельского хозяйства, борьба с эрозией почв, болезнями и вредителями сельскохозяйственных культур и животных, экономическая отсталость сельских товаропроизводителей и др.). Виды, разновидности, формы, пространство и время политического воздействия в таких случаях вмешательства государства в процесс аграрного производства определяются в нормативном порядке, но с учетом специфики соответствующего участка производства и объективных оснований (предпосылок) его возникновения.

При этом правовое присутствие в аграрном поле политики не подменяет политическое регулирование правовым регламентированием. Реализация государственного воздействия на аграрное производство осуществляется политическими усилиями, свойственными политическому влиянию. Здесь сфера нормативного регулирования и сфера аграрной политики не совпадают по объему и возможностям, заложенным в них. Политическая деятельность включает в себя ряд специфических способов воздействия на аграрную экономику, таких, как формирование политического сознания, организацию познания политической теории и реализацию политического сознания (политическое просвещение - информирование, пропаганда, агитация, привлечение всех механизмов политической деятельности, например, обсуждение направлений, хода и результатов аграрной политики в структурах гражданского общества и т.д.). К сожалению (и это следует особо отметить), в условиях декларативности правоположений, регулирующих аграрные отношения в стране, заранее известной их нереализуемости и неиспол-

\footnotetext{
${ }^{27}$ Ханнанов Р.А. Правовая природа бездействия и каузальность // Советское государство и право. 1978. № 4. С. 124-128.
} 


\section{Право и политика $4(160) \cdot 2013$}

няемости, фактической абъюративности, догматической предобусловленности агрохозяйственной деятельности в России нормативные каноны ведения сельского хозяйства и АПК «забываются» и подменяются усмотрением власть имущих, аграрная политика уходит от объективных факторов бытия, превращается в дискреционную политику. Оставшиеся нереализованными в течение ХХвека всевозможные целевые программы подъема агропрома (коллективизации, мелиорации, химизации, интенсификации, интеграции, реформации и др.) бескомпромиссно подтверждают вышесказанные утверждения. Механизм реализации государственной аграрной политики, представляемый в процессном виде и включающий в себя совокупность объективно обусловленных общественных обстоятельств и сложившихся в форме «общественных потребностей (экономические интересы участников аграрных отношений) целей (достижение устойчивости и эффективности аграрного производства и обеспечение требований норм аграрного права в сфере организации и ведения производства и соблюдения государственной аграрной хозяйственной дисциплины) $\rightarrow$ позитивно результативной агрохозяйственной деятельности», остается на уровне пожеланий. Детерминанты государственной аграрной политики (природная обусловленность жизнедеятельности человека и изменения, происходящие в биосфере), при такой ситуации, не смогли объективироваться изза недостаточности внимания к ним со стороны государственных органов власти и хозяйственного управления, отсутствия должной реакции на получившие распространение социальные события, ставшие «непосредственной данностью» в силу их многократного повторения, факты неисполнения норм, обязывающих учитывать изменение биоклиматического потенциала планеты, формирования статуса стереотипной безответственности (социального события) исполнителей закона (норм аграрного права), утвердившегося безразличия товаропроизводителей к результатам аграрного производства, иными словами - игнорирования субъективации объективности: ожидание улучшений погоды («Бог даст»;«был бы дождик», «был бы гром»), надежды на государственную поддержку сельского хозяйства и АПК (льготы, преференции, страховые возмещения, инвестиции, списания долгов и т.д. и т.п.)!

Что касается использования ненормативных правил политического поведения, то следует констатировать закономерный характер их зарождения без непосредственного участия государства В их основе лежат объективно обусловленные экономические интересы субъектов агрохозяйственных связей, потребности в воспроизводстве сельскохозяйственной продукции, понимаемые в контексте самообеспечения продуктами питания, продовольствием, необходимость достижения продовольственной безопасности людей, т.е. объективно-субъективный фактор, олицетворяющий слияние природного и духовного, генерирующий политическое поведение политических акторов.

Однако ненормативность поведения политических акторов нельзя представлять в виде социальной свободы. Политическая деятельность и в таком случае возбуждается общими конституционными нормами государства о: власти (ст. 3 Конституции РФ), гражданстве (ст. 6), свободном развитии человека (ст. 7), разделении власти (ст. 10), местном самоуправлении (ст. 12), политическом многообразии (ст. 13), свободе мысли и слова (ст. 29), участии в управлении землями государства (ст. 32), частной собственности на землю, владении, пользовании и распоряжении земельными и другими природными ресурсами (ст. 36) и др., и реализуется в соответствии с духом и буквой закона и подзаконных актов, посвященных регулированию политических отношений, согласно нормативным условиям, обеспечивающим движение политических прав и обязанностей ${ }^{28}$, а при отсутствии таковых - социальными нормами, отвечающими требованиям правопорядка, представлениям о добре и зле, справедливости, экономической выгодности. На деле это означает, что при выборе конкретных видов, разновидностей, форм, методов, способов субъективации объективного, выбора соответствующих им действий (бездействия), следует руководствоваться средствами индивидуального регулирования, творческого мышления, анализа агрохозяйственной (техникотехнологической, экономической, трудовой, социальной и т.п.) ситуации, подходя к ней с позиций их целесообразности, доступности, выгодности, достижимости, выполнимости в условиях объективно существующих (сложившихся) «непосредственных данностей». Перечни таких действий не могут быть предусмотрены в нормативном порядке. В противном случае они сковывали бы производственно-хозяйственную инициативу сельских и причастных к сельскохозяйственной деятельности лиц, выглядели бы как непозволительное вмешательство в их исконно проводимую, ставшую повседневностью работу, их самобытность, подверженную саморегулированию.

В реальной действительности таких действий великое множество. Каждое из них обуславливается, возбуждается, детерминируется объективным законом саморегуляции природы и в дальнейшем развитии одухотворяется, получает субъективную оценку, объективируется в форме прямой связи до уровня практической агрохозяйственной деятельности, затем объективируется в форме обратной связи. Так, плодородие почв - основное природное свойство земли (объективное) - инициирует совокупные усилия государства и товаропроизводителей по сохранению и восстановлению самого себя (субъективное), совершению

\footnotetext{
${ }^{28}$ Ханнанов Р.А. Нормативные условия в динамике гражданского правоотношения // Советское государство и право. 1973. № 8. C. $123-127$.
} 
комплекса почвозащитных мероприятий; биологическая зависимость сельскохозяйственных культур от биоресурсной емкости водопотребления и водообеспечения (объективное) требует задействования совокупных водохозяйственных мероприятий; природная обусловленность жизненного цикла животных, непрерывность, перманентность производства, естественная генуинность (объективное) подсказывают, сигнализируют о необходимости привлечения в сферу животноводства особых мер обеспечения развития подотрасли (субъективное) и т.д., в конечном счете - возведение их в содержательный элемент государственной аграрной политики.

Подобный двуединый, дуалистический подход к организации совмещения объективного с субъективным и, наоборот, субъективного с объективным в аграрном производстве, следовательно, во всей агроэкономической среде, позволяет свести материальное с духовным в процессе агропроизводства, осуществить переход сельского хозяйства и АПК на инновационную и модернизированную, устойчивую и эффективную почву функционирования. Обеспечение их симбиотического существования и устранение возникающих между ними противоречий, отказ от негативного отношения к объективному (природному, естественному) и поддержки доминантно субъективного, догматического в отрасли и в ее звеньях, по нашему мнению, является неотложной и приоритетной задачей аграрной политики государства.

\section{Библиография:}

1. Ушачев И. Система управления - основа реализации модели инновационного развития АПК России [Текст] / И. Ушачев // АПК: экономика, управление. 2013. № 1. С. 13.

2. Ханнанова T.Р. Аграрная политика государства: критика догмы [Текст] / Т.Р. Ханнанова // Теория и практика общественного развития. 2013. № 2.

3. Алтухов А. Новые проблемы развития зерновой отрасли [Текст] / А. Алтухов // АПК: экономика, управление. 2011. № 1. С. 10-21;

4. Романенко Г. Обеспечить модернизацию агропромышленного комплекса [Текст] / Г. Романенко// АПК: экономика, управление. 2011. № 3. С. 3-10;

5. Шутьков А. Аграрная политика: социально-экономические проблемы [Текст] / А. Шутьков // АПК: экономика, управление. 2011. № 5. С. 3-9;

6. Буздалов И. Земельная реформа: взгляд сквозь призму замысла [Текст] / И. Буздалов // АПК: экономика, управление. 2012. № 7. С. 3-17;

7. Ушачев И.Г. О мерах по обеспечению конкурентноспособности продукции Российского сельского хозяйства в условиях присоединения к ВТО [Текст]
/ И.Г. Ушачев // Агропроизводственная политика России. 2012. № 7. С. 2-7;

8. Ушачев И., Алтухов А. Территориально-отраслевое разделение труда - основной фактор развития агропромышленного производства России [Текст] / И. Ушачев, А Алтухов // АПК: экономика, управление. 2011. № 8. С. 3-12;

9. Ушачев И. Экономический механизм реализации Государственной программы развития сельского хозяйства и регулирования рынков сельскохозяйственной продукции, сырья и продовольствия на 2013-2020 годы [Текст] / И. Ушачев // АПК: экономика, управление. 2012. № 11. С. 3-7;

10. Ушачев И. Система управление - основа реализации модели инновационного развития АПК России [Текст] / И. Ушачев // АПК: экономика, управление. 2013. № 1. С. 13-21;

11. Воронин Б.А., Ханнанов Р.А., Ханнанова Т.Р. Новые концептуальные основы обеспечения устойчивости аграрного производства [Текст] / Б.А. Воронин, Р.А. Ханнанов, Т.Р. Ханнанова // Аграрный вестник Урала. 2012. № 6. С. 81-89;

12. Ханнанов Р.А., Ханнанова Т.Р. Кластеризация экономики и государственная кластерная политика: теоретические основы и социально-экономические предпосылки [Текст] / Ханнанов Р.А., Ханнанова T.P. // Евразийский юридический журнал. 2012. № 12. C. 129-135.

13. Путин В.В. О наших экономических задачах [Текст] // Ведомости 2012. 30 января.

14. Крысин Л.П. Толковый словарь иноязычных слов [Текст] / Л.П. Крысин; М.: Эксмо, 2007. - 944 с. C. 534.

15. А.Н. Азрилиян. Новый экономический словарь [Текст] / А.Н. Азрилян; М.: Институт новой экономики, 2006. - 1088 с. - С. 467.

16. Энгельс Ф. Происхождение семьи, частной собственности и государства [Текст] / К. Маркс, Ф. Энгельс; Соч. 2-ое изд. Т. 21. С.

17. Ханнанов Р.А., Ханнанова Т.Р. События в системе правового обеспечения модернизации социальноэкономического развития России: теория и практика [Текст] / Р.А. Ханнанов, Т.Р. Ханнанова // Уфа, Башкирский ГАУ, АН РБ, - 2012. - 162 с. - С. 44.

18. Ханнанова Т.Р. Концептуальные основы аграрной политики [Текст] / Т.Р. Ханнанова // Мир и политика. 2013. № 2. С.

19. Хицков И. Системность - определяющий фактор разумного хозяйствования [Текст ] / И. Хицков // АПК: экономика, управление. 2012. № 8. С. 13-14 и др.

20. Атаманчук Г.В. Теория государственного управления: курс лекций [Текст] / Г.В. Атаманчук // 4 изд., стер. М.: Омега-Л, 2006. - 384 с. - С. 456. 


\section{Право и политика 4 (160) 2013}

\section{References (transliteration):}

1. Ushachev I. Sistema upravleniya - osnova realizatsii modeli innovatsionnogo razvitiya APK Rossii [Tekst] / I. Ushachev // APK: ekonomika, upravlenie. 2013. № 1. S. 13.

2. .Khannanova T.R. Agrarnaya politika gosudarstva: kritika dogmy [Tekst] / T.R. Khannanova // Teoriya i praktika obshchestvennogo razvitiya. 2013. № 2.

3. Altukhov A. Novye problemy razvitiya zernovoy otrasli [Tekst] / A. Altukhov // APK: ekonomika, upravlenie. 2011. № 1. S. 10-21;

4. Romanenko G. Obespechit' modernizatsiyu agropromyshlennogo kompleksa [Tekst] / G. Romanenko// APK: ekonomika, upravlenie. 2011. № 3. S. 3-10;

5. Shut'kov A. Agrarnaya politika: sotsial'no-ekonomicheskie problemy [Tekst] / A. Shut'kov // APK: ekonomika, upravlenie. 2011. № 5. S. 3-9;

6. Buzdalov I. Zemel'naya reforma: vzglyad skvoz' prizmu zamysla [Tekst] / I. Buzdalov // APK: ekonomika, upravlenie. 2012. № 7. S. 3-17;

7. Ushachev I.G. O merakh po obespecheniyu konkurentnosposobnosti produktsii Rossiyskogo sel'skogo khozyaystva v usloviyakh prisoedineniya k VTO [Tekst] / I.G. Ushachev // Agroproizvodstvennaya politika Rossii. 2012. № 7. S. 2-7;

8. Ushachev I., Altukhov A. Territorial'no-otraslevoe razdelenie truda - osnovnoy factor razvitiya agropromyshlennogo proizvodstva Rossii [Tekst] / I. Ushachev, A Altukhov // APK: ekonomika, upravlenie. 2011. № 8. S. 3-12;

9. Ushachev I. Ekonomicheskiy mekhanizm realizatsii Gosudarstvennoy programmy razvitiya sel'skogo khozyaystva i regulirovaniya rynkov sel'skokhozyaystvennoy produktsii, syr'ya i prodovol'stviyana 2013-2020 gody [Tekst] / I. Ushachev // APK: ekonomika, upravlenie. 2012. № 11. S. 3-7;

10. Ushachev I. Sistemaupravlenie - osnova realizatsii modeli innovatsionnogo razvitiya APK Rossii [Tekst] / I. Ushachev // APK: ekonomika, upravlenie. 2013. № 1. S. 13-21;
11. Voronin B.A., Khannanov R.A., Khannanova T.R. Novye kontseptual'nye osnovy obespecheniya ustoychivosti agrarnogoproizvodstva [Tekst] / B.A. Voronin, R.A. Khannanov, T.R. Khannanova // Agrarnyy vestnikUrala. 2012. № 6. S. 81-89;

12. Khannanov R.A., Khannanova T.R. Klasterizatsiya ekonomiki i gosudarstvennaya klasternaya politika: teoreticheskie osnovy i sotsial'no-ekonomicheskie predposylki [Tekst] / Khannanov R.A., Khannanova T.R. // Evraziyskiy yuridicheskiy zhurnal. 2012. № 12. S. 129-135.

13. Putin V.V. O nashikhekonomicheskikhzadachakh [Tekst] // Vedomosti 2012. 30 yanvarya.

14. Krysin L.P. Tolkovyy slovar' inoyazychnykh slov [Tekst] / L.P. Krysin; M.: Eksmo, 2007. - 944 s. - S. 534.

15. A.N. Azriliyan. Novyyekonomicheskiyslovar' [Tekst] / A.N. Azrilyan; M.: Institutnovoyekonomiki, 2006. - 1088 S. - S. 467.

16. Engel's F. Proiskhozhdeniesem'i, chastnoysobstvennosti i gosudarstva [Tekst] / K. Marks, F. Engel's; Soch. 2-oe izd. T. 21. S.

17. Khannanov R.A., Khannanova T.R. Sobytiya v siste mepravovogoobespecheniyamodernizatsiisotsial'noekonomicheskogorazvitiyaRossii: teoriya i praktika [Tekst] / R.A. Khannanov, T.R. Khannanova // Ufa, Bashkirskiy GAU, AN RB, - 2012. - 162 s. - S. 44.

18. Atamanchuk G.V. Teoriyagosudarstvennogoupravleniya: kurslektsiy [Tekst] / G.V. Atamanchuk // 4 izd., ster. - M.: Omega-L, 2006. - 384 s. - S. 456.

19. Voronin B.A., Khannanov R.A., Khannanova T.R. Novye kontseptual'nyeosnovyobespecheniyaustoychivostiagrarn ogoproizvodstva [Tekst] / B.A. Voronin, R.A. Khannanov, T.R. Khannanova// AgrarnyyvestnikUrala. 2012. №6. S. 8189; Khannanova T.R. Kontseptual'nyeosnovyagrarnoyp olitiki [Tekst] / T.R. Khannanova // Mir i politika. 2013. № 2; Khannanova T.R. Agrarnayapolitikagosudarstva: kritikadogmy [Tekst] / T.R. Khannanova // Teoriya i pra ktikaobshchestvennogorazvitiya. 2013. № 2 .

20. Voronin B.A., Khannanov R.A., Khannanova T.R. Sovreme nnyeproblemypravovogoregulirovaniyaagrarnykhotnosheniy [Tekst] / B.A. Voronin, R.A. Khannanov, T.R. Khannanova // AgrarnyyvestnikUrala. 2012. № 10. S. 52-56. 